\title{
Mechanism Study on Corporate Social Responsibilities between Agricultural Product and Brand Trust
}

\author{
Ling Jia \\ School of Business, Jiangxi Normal University, Nanchang, P. R. China, 330022
}

Keywords: corporate social responsibility, perceived risk, brand trust

\begin{abstract}
It is an important driving factor for enterprises to undertake the corporate social responsibility for rebuilding consumers' brand trust. In this thesis, the mechanism model is proposed to construct that the corporate social responsibility of eco-agricultural products impacting consumers' brand trust. There is a questionnaire for the consumers of eco-agricultural products. The multivariate regression analysis is adopted to make empirical research for hypothesis model. This study shows that consumers and environmental responsibility have a significant negative impact on perceived risk, while have a significant positive impact on brand trust. Meanwhile, the brand trust is negatively impacted by the perceived risk. Besides, the perceived risk plays a mediating role between corporate social responsibilities and brand trust. The above study shows that there is certain theoretical guiding significance for eco-agricultural product enterprises to implement corporate social responsibility strategy.
\end{abstract}

\section{Introduction}

In recent years, a number of agricultural products enterprises in China didn't pay much attention to corporate social responsibility. A series of events, such as "poison leek in Qingdao" and "aflatoxin exceeding the standard of Mengniu" etc, caused serious brand trust crisis. In this case, how to enhance the consumers brand trust has become an urgent problem for many agricultural products enterprises. However, some enterprises have taken social responsibility to improve the brand image and obtain consumer trust. For example, Life Water's "public welfare action of water half bottle", by the end of 2016, it has helped solve the problem of drinking water for more than 530 thousand children in the water shortage area, and has gained 6 times more sales for the company while gaining a lot of positive word of mouth and trust. So what is the impact of corporate social responsibility on brand trust? At present, the research on corporate social responsibility in academia is mainly focused on actively taking social responsibilities enabling enterprises to get higher evaluation ${ }^{[1]}$, and improving consumers' purchase intention ${ }^{[2]}$. However, the relationship between corporate social responsibility and brand trust is still lacking deeper research. Then, will the social responsibility of agricultural products have an impact on consumer brand trust? What is the mechanism between them? Based on the above analysis, this paper introduces the intermediary variable of perceived risk to explore the mechanism between social responsibility of agricultural products and brand trust.

\section{Hypothesis and Model Building}

\subsection{Corporate Social Responsibility and Perceived Risk}

Corporate social responsibility (CSR) is "the state and behavior of an enterprise when perceiving its social obligations" ${ }^{11]}$. At present, most scholars believe that corporate social responsibility (CSR) includes four dimensions: economic responsibility, legal responsibility, ethical responsibility and charitable responsibility ${ }^{[5]}$. But because of limited access to information and intention, consumers often have a higher perception about consumer responsibility, environmental responsibility and charitable responsibility and community perception ${ }^{[6]}$, which is highly related to themselves, and not the actual performance of enterprise about corporate social responsibility. Therefore, this 
research holds that corporate social responsibility should mainly include four aspects of consumer responsibility, environmental responsibility, community responsibility and charitable responsibility. Because of information asymmetry, consumers are prone to form a perceived risk when they make a purchase decision. Perceived risk is the possibility of uncertainty and adverse consequences perceived by consumers when buying products or services ${ }^{[7]}$. For agricultural products, it has more attributes of trust goods. Consumers have higher perceived risk when they buy agricultural products. When the enterprise taking social responsibility, it is easy to form a sense of "sense of security" and reduce perceived risk for consumer. Therefore, the following hypothesis are put forward:

H1: corporate social responsibility has a significant negative impact on perceived risk

H1a: consumer responsibility has a significant negative impact on perceived risk

H1b: environmental responsibility has a significant negatively affects on perceived risk

H1c: community responsibility has a significant negatively affects on perceived risk

H1d: charitable responsibility has a significant negatively affects on perceived risk

\subsection{Corporate Social Responsibility and Brand Trust}

Brand trust is the expectation of consumers' confidence in brand reliability and brand intention under the condition of risk ${ }^{[10]}$. It also represents consumers security sense for brand ${ }^{[11]}$. Therefore, Delgado-Ballester (2003) sums up brand trust into the two dimensions of brand reliability and brand intention ${ }^{[10]}$. On this basis, Yuan ${ }^{[12]}$ (2007) details brand trust into the three dimensions of quality trust, intention trust and capability trust. In this study, Yuan ${ }^{[12]}$ (2007)'s method is approved and used for reference. With the increasing awareness of corporate social responsibility, consumers' attitude towards enterprises has improved significantly ${ }^{[2]}$. Corporate social responsibility plays an important role in the formation process of consumer brand attitude ${ }^{[3]}$. Liu Fengjun has proved that corporate social responsibility has a direct and positive impact on brand attitude through research ${ }^{[4]}$. Brand attitude is the direct driving factor of brand trus $\mathrm{t}^{[20]}$. Therefore, the following hypothesis are put forward:

H2: corporate social responsibility has a significant positive impact on brand trust

H2a: consumer responsibility has a significant positive impact on brand trust

H2b: environmental responsibility has a significant positive impact on brand trust

H2c: community responsibility has a significant positive impact on brand trust

H2d:'s charitable responsibility has a significant positive impact on brand trust

\subsection{Perceived Risk and Brand Trust}

Brand trust is generated when consumers are facing risks ${ }^{[10,11,13]}$. Brand trust is closely related to perceived risk. Li Man (2014) ${ }^{[14]}$ studies confirm that the perceived risk in the network service scene will significantly affect the consumer's initial trust. And consumers' trust on green brands also comes from the degree of their perceived risk ${ }^{[15]}$. The higher of the consumer perceived risk, the lower of the trust on the brand. That is, the perceived risk significant negatively affects the consumer trust ${ }^{[16]}$. Therefore, the following hypothesis is put forward:

H3: perceived risk has a significant negative impact on brand trust

\subsection{The Mediating Effect of Perceived Risk}

The unique attributes of agricultural products cause serious information asymmetry between consumers and agricultural products enterprises. It is difficult for consumers to grasp product quality information, which is easy to form perceived risk. But when consumers receive the information of "responsible information", they will use the information to judge the quality of products, and tend to think that the enterprise is a company that is actively responsible for social responsibility, and the quality of products is guaranteed, so as to reduce perceived risk. And perceived risk is an important factor that affects consumer brand trust. The higher the perceived risk is, the lower the brand trust is ${ }^{[14,15,16]}$. Therefore, corporate social responsibility can play a role in brand trust through perceived risk. Therefore, the following hypothesis is put forward:

H4: perceived risk plays an intermediary role in the relationship between corporate social responsibility and brand trust 
H4a: perceived risk plays an intermediary role in the relationship between consumer responsibility and brand trust

H4b: perceived risk plays an intermediary role in the relationship between environmental responsibility and brand trust

H4c: perceived risk plays an intermediary role in the relationship between community responsibility and brand trust

H4d: perceived risk plays an intermediary role in the relationship between charitable responsibility and brand trust

Based on the above hypothesis, we propose a research hypothesis model among origin image, product perceived quality and brand trust, which is shown in the following figure 1 .

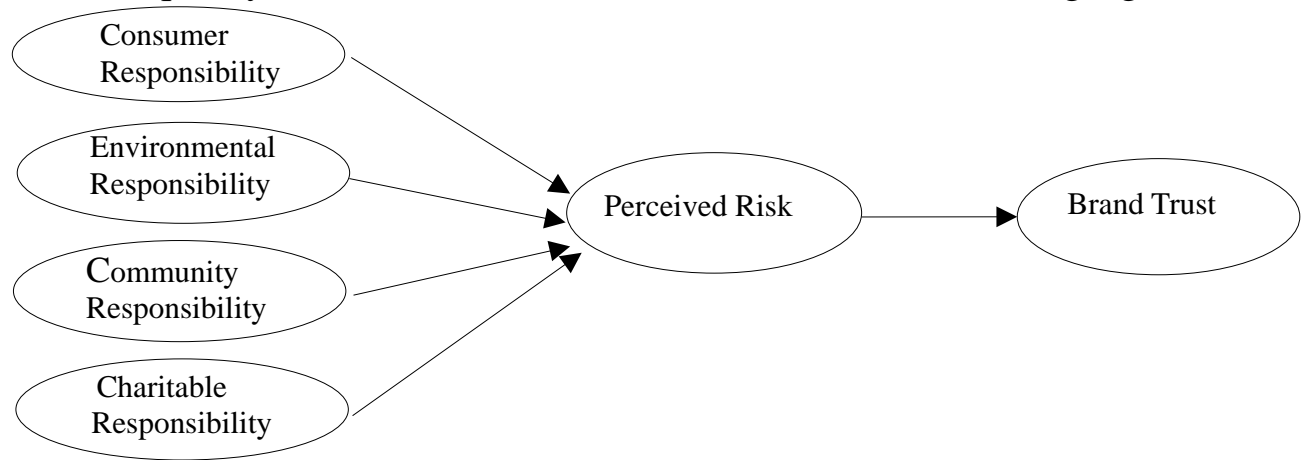

Figure 1 Research Model

\section{Research Methods}

\subsection{Variable Measurement}

In order to ensure the content validity of the scale, the measurement scales used in this study were formed on the basis of the maturity scale and questionnaire survey. Among them, the corporate social responsibility consists of 10 measurement items, mainly based on the development scale of RepuTex and Jin India ${ }^{[17]}$. The perceived risk includes 6 measurement items, mainly coming from Kaplan's and Peters' scale ${ }^{[8,9]}$. Brand trust contains 6 measurement items, mainly correcting on Delgado-Ballest's ${ }^{[10]}$ and Yuan's ${ }^{[12]}$ development scale. There are five level scales in the all measurement items ( 1 = strongly disagree, 5 = strongly agree).

\subsection{Research Sample}

In this study, the data are collected through the implementation of online research and offline research. 500 online survey questionnaires are issued, 478 are returned and 445 are the valid questionnaires. The basic characteristics of the valid samples are as follows. In terms of gender, male is $42.47 \%$ and female is $57.53 \%$. In terms of age, $3.37 \%$ is between $18-30$ years old, $4.27 \%$ is between $31-40$ years old, and $92.36 \%$ is above 41 years old. In terms of education, $3.1 \%$ is for primary education, $28.5 \%$ is for high school and secondary education, and $68.4 \%$ is for college degree or above. In terms of occupation, $26.3 \%$ is for civil servant and institution staff, $31.2 \%$ is for enterprise employee, $37.8 \%$ is for self-employed and $4.7 \%$ is for the other occupations. In terms of income level, $1.2 \%$ is for annual income of 20,000 Yuan or below, $18.1 \%$ is for annual income between 20,000 Yuan and 60,000 Yuan, 30.3\% is for annual income between 60,000 Yuan and 100,000 Yuan, and 50.4\% is for annual income above 100,000 Yuan. From the sample descriptive statistics, there are more women and high-income consumers.

\section{Analysis Results}

\subsection{Reliability Test}

Being an important indicator of data quality, data reliability refers to whether a measurement item measures the same conception. In the empirical study, the academia generally adopts internal 
consistency coefficient (Cronbach'a value) to test data reliability. In this study, the internal consistency coefficient (Cronbach'a value) for each variable is shown in Table 1. As shown in Table 1 , the Cronbach'a values of the all variables are greater than 0.7. The overall questionnaire Cronbach'a value is 0.887 , which indicates that there are high internal consistency and good reliability for the sample data.

\subsection{Validity Test}

Validity includes content validity, convergent validity and discriminant validity. Content validity is an assessment of scale effectiveness. There is good content validity, because the mature scale frequently used by domestic and foreign scholars is adopted in this study.

Convergent validity is a significant correlation among the different items of the same conception. As shown in Table 1, KMO value of each variable is greater than 0.7 , the factor loading value is more than 0.5 , and the $\mathrm{P}$ value is significant. These indicate that each measurement index converges to the corresponding factor and each variable has good convergent validity.

Table 1 Correlation values for each variable

\begin{tabular}{|c|c|c|c|c|c|c|}
\hline $\begin{array}{c}\text { Research } \\
\text { dimensions }\end{array}$ & $\begin{array}{l}\text { Factor } \\
\text { name }\end{array}$ & $\begin{array}{c}\text { Factor loading } \\
\text { value }\end{array}$ & $\begin{array}{l}\text { Numbe of mea- } \\
\text { sureement items }\end{array}$ & $\begin{array}{l}\text { Cronbach's } \\
\text { Alpha value }\end{array}$ & P value & $\begin{array}{l}\text { KMO } \\
\text { value }\end{array}$ \\
\hline Overall variables & - & - & 26 & 0.919 & - & - \\
\hline \multirow{2}{*}{$\begin{array}{c}\text { Consumer } \\
\text { responsibility }\end{array}$} & CR1 & 0.879 & \multirow[t]{2}{*}{2} & \multirow[t]{2}{*}{0.723} & \multirow[t]{10}{*}{0.000} & \multirow[t]{10}{*}{0.836} \\
\hline & CR2 & 0.727 & & & & \\
\hline \multirow{2}{*}{$\begin{array}{l}\text { Environmental } \\
\text { responsibility }\end{array}$} & ER1 & 0.692 & \multirow[t]{2}{*}{2} & \multirow[t]{2}{*}{0.865} & & \\
\hline & ER2 & 0.797 & & & & \\
\hline \multirow{3}{*}{$\begin{array}{l}\text { Community } \\
\text { responsibility }\end{array}$} & COR1 & 0.876 & \multirow[t]{3}{*}{3} & \multirow[t]{3}{*}{0.781} & & \\
\hline & COR2 & 0.536 & & & & \\
\hline & COR3 & 0.810 & & & & \\
\hline \multirow{3}{*}{$\begin{array}{c}\text { Charitable } \\
\text { responsibility }\end{array}$} & CHR1 & 0.834 & \multirow[t]{3}{*}{3} & \multirow[t]{3}{*}{0.845} & & \\
\hline & CHR2 & 0.788 & & & & \\
\hline & CHR3 & 0.831 & & & & \\
\hline \multirow[t]{6}{*}{ Perceived risk } & PR1 & 0.750 & \multirow[t]{6}{*}{6} & \multirow[t]{6}{*}{0.899} & \multirow[t]{6}{*}{0.000} & \multirow[t]{6}{*}{0.868} \\
\hline & PR2 & 0.805 & & & & \\
\hline & PR3 & 0.863 & & & & \\
\hline & PR4 & 0.861 & & & & \\
\hline & PR5 & 0.826 & & & & \\
\hline & PR6 & 0.788 & & & & \\
\hline \multirow[t]{6}{*}{ Brand trust } & BT1 & 0.734 & \multirow[t]{6}{*}{6} & \multirow[t]{6}{*}{0.885} & \multirow[t]{6}{*}{0.000} & \multirow[t]{6}{*}{0.882} \\
\hline & $\mathrm{BT2}$ & 0.791 & & & & \\
\hline & BT3 & 0.810 & & & & \\
\hline & BT4 & 0.809 & & & & \\
\hline & BT5 & 0.858 & & & & \\
\hline & BT6 & 0.781 & & & & \\
\hline
\end{tabular}

Discriminant validity is a difference degree to measure the characteristics aspect among the items of different conception, Hair et al. ${ }^{[19]}$ (2006) put forward that there is discriminant validity among the variables, when the 95\% confidence interval of the two potential variables' correlation coefficients does not cover 1.00. The correlation value of each variable in this study is shown in Table 2. Person correlation coefficients of each variable are between -0.149-0.633 and the confidence interval of the relevant coefficient does not contain 1.00. These indicate that there is a significant difference among the variables and the discriminant validity is good.

Table 2 Correlation coefficient for each variable

\begin{tabular}{|l|c|c|c|c|c|c|}
\hline & IC & NE & HQ & PA & PQ & QT \\
\hline Consumer responsibility & $\mathbf{1}$ & & & & & \\
\hline Environmental responsibility & $0.562^{* *}$ & 1 & & & & \\
\hline Community responsibility & $0.438^{* *}$ & $0.581^{* *}$ & 1 & & & \\
\hline Charitable responsibility & $0.426^{* *}$ & $0.486^{* *}$ & $0.536^{* *}$ & 1 & & \\
\hline Perceived risk & $0.395^{*}$ & $0.558^{* *}$ & $0.347^{* *}$ & $0.385^{*}$ & 1 & \\
\hline Brand trust & $0.569^{* *}$ & $0.348^{*}$ & $0.573^{* *}$ & $0.482^{* *}$ & $0.409^{* *}$ & 1 \\
\hline
\end{tabular}

Note: $*$ is $\mathrm{p}<0.05, * *$ is $\mathrm{p}<0.01$ 


\subsection{Hypothesis Test}

Table 3 Hypothesis test results table

\begin{tabular}{|c|c|c|c|c|c|}
\hline \multicolumn{2}{|c|}{ Original hypothesis } & \multirow{2}{*}{$\begin{array}{c}\text { Standardization } \\
\text { path coefficient } \\
-0.138^{*}\end{array}$} & \multirow{2}{*}{$\begin{array}{l}\text { T value } \\
-2.372\end{array}$} & \multirow{2}{*}{$\begin{array}{c}\text { P value } \\
0.015\end{array}$} & \multirow{2}{*}{$\begin{array}{l}\text { Conclusion } \\
\text { Support }\end{array}$} \\
\hline $\mathrm{H} 1$ & $\begin{array}{l}\text { H1a: consumer responsibility has a significant } \\
\text { negative impact on perceived risk }\end{array}$ & & & & \\
\hline & $\begin{array}{l}\text { H1b: environmental responsibility has a } \\
\text { significant negatively impact on perceived risk }\end{array}$ & $-0.123 *$ & -2.218 & 0.023 & Support \\
\hline & $\begin{array}{l}\text { H1c: community responsibility has a significant } \\
\text { negatively impact on perceived risk }\end{array}$ & -0.010 & -0.112 & 0.874 & Not Support \\
\hline & $\begin{array}{l}\text { H1d: charitable responsibility has a significant } \\
\text { negatively impact on perceived risk }\end{array}$ & -0.043 & -0.470 & 0.651 & Not Support \\
\hline \multirow[t]{4}{*}{$\mathrm{H} 2$} & $\begin{array}{l}\text { H2a: consumer responsibility has a significant } \\
\text { positive impact on brand trust }\end{array}$ & $0.258 * *$ & 3.989 & 0.000 & Support \\
\hline & $\begin{array}{l}\text { H2b: environmental responsibility has a } \\
\text { significant positive impact on brand trust }\end{array}$ & $0.183^{* *}$ & 2.645 & 0.009 & Support \\
\hline & $\begin{array}{l}\text { H2c: community responsibility has a significant } \\
\text { positive impact on brand trust }\end{array}$ & 0.069 & 1.008 & 0.315 & Not Support \\
\hline & $\begin{array}{l}\text { H2d:'s charitable responsibility has a significant } \\
\text { positive impact on brand trust }\end{array}$ & 0.068 & 1.042 & 0.299 & Not Support \\
\hline H3 & $\begin{array}{l}\text { H3: perceived risk has a significant negative } \\
\text { impact on brand trust }\end{array}$ & $-0.149 * *$ & -2.667 & 0.007 & Support \\
\hline
\end{tabular}

Note: $*$ is $\mathrm{p}<0.05, * *$ is $\mathrm{p}<0.01$

We adopt a multivariate regression method to make the empirical test for the research hypothesis. The results are shown in Table 3. The two dimensions of corporate social responsibility have a significant negative impact on perceived risk. There into, Consumer responsibility impact is the strongest and its standardization path coefficient is -0.138 . Community responsibility impact takes second place and its standardization path coefficient is -0.123 . The two dimensions of corporate social responsibility have a significant direct positive impact on brand trust. There into, Consumer responsibility impact is the strongest and its standardization path coefficient is 0.258 . Community responsibility impact takes second place and its standardization path coefficient is 0.183 . Perceived risk has a significant negative impact on brand trust and its standardization path coefficient is -0.149 . Community responsibility and charitable responsibility have not a significant impact on perceived risk and brand trust because of the $\mathrm{P}$ value $>0.05$.

\subsection{Mediating Effect Test}

About mediating effect test, most researchers have adopted the ordinal regression test method proposed by Baron and Kenny ${ }^{[18]}$. In this method, mediating effect test is logically intuitive and visual, and it is easy to be understood and operated. In this study, the mediating effect test method of Baron and Kenny is also adopted.

At first, regression analysis is made for the relation between origin image and perceived quality, according to the mediating effects test method of Baron and Kenny. The results are shown in Table 4. Consumer responsibility standardization regression coefficient for perceived risk is $\beta=-0.161$ and $\mathrm{P}$ value is $<0.05$, so consumer responsibility has a significant impact on perceived risk. Then, regression analysis is made for perceived rick impact on brand trust. Perceived risk standardization regression coefficient for brand trust is $\beta=-0.124$ and $\mathrm{P}$ value is $<0.05$, so perceived quality has a significant impact on brand trust. Next, regression analysis is made for consumer responsibility impact on brand trust. Consumer responsibility standardization regression coefficient for brand trust is $\beta=0.549$ and $P$ value is $<0.001$, so consumer responsibility has a significant impact on brand trust. Finally, regression analysis is made for both consumer responsibility and perceived risk's impact on brand trust. The results are shown in Table 4. There is no significant change for consumer responsibility's direct impact on brand trust ( $\mathrm{P}$ value is $0.000<0.05$ ). However, the effect intensity is significantly reduced and is from 0.549 down to 0.529 . These indicate that perceived risk plays an intermediary role for consumer responsibility impact on brand trust. Similarly, perceived risk plays an intermediary role for environmental responsibility impact on brand trust. 
Table 4 Mediating effect test

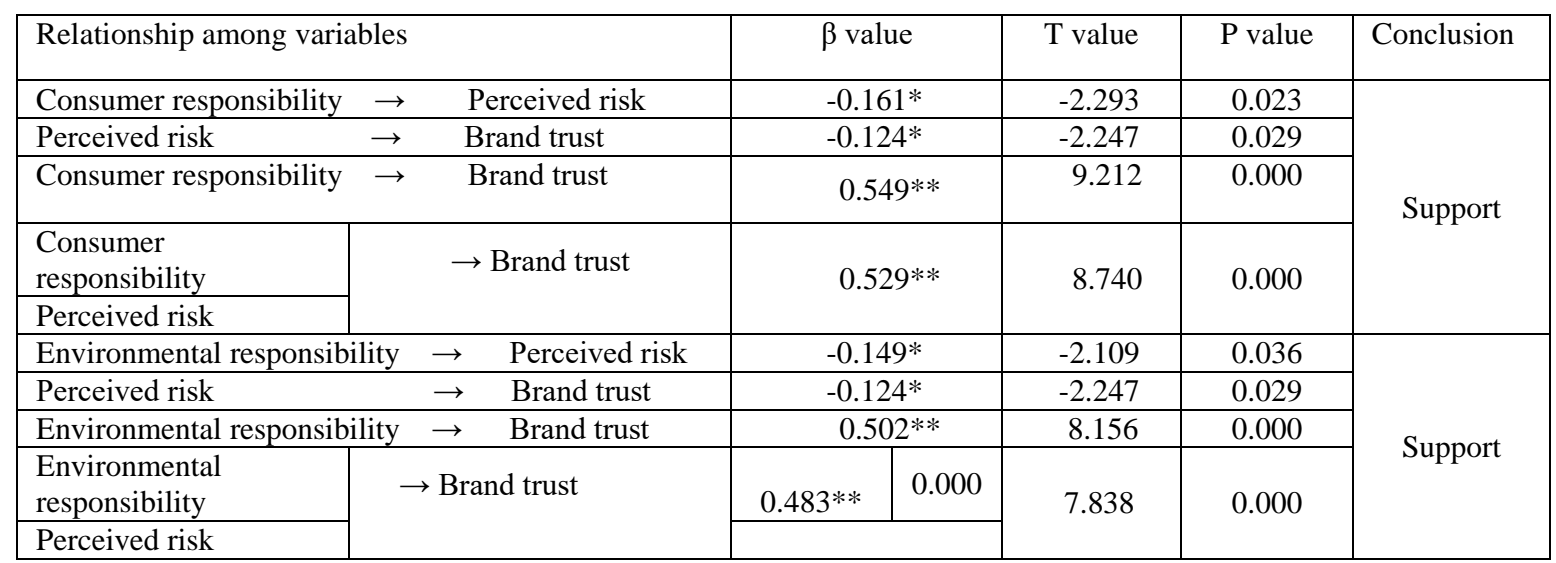

Note: $*$ is $\mathrm{p}<0.05, * *$ is $\mathrm{p}<0.01$

\section{Conclusions and Enlightenment}

\subsection{Conclusions}

Based on the review of corporate social responsibility on the existing research, this study constructs the model of gricultural corporate social responsibility on brand trust. I use multiple regression method to verify the assumptions, and the main conclusions are as follows: (1) the consumer and environmental responsibility directly influences the perceived risk and brand trust. In the four dimensions of social responsibility of agricultural products enterprises, the direct impact of consumer responsibility on perceived risk and brand trust are the strongest, and environmental responsibility is the second one. (2) Perceived risk has a direct impact on brand trust. (3) Consumer responsibility and environmental responsibility play a role in brand trust throuh perceived risk, and perceived risk has a close mediating effect between consumer responsibility and environmental responsibility and brand trust.

\subsection{Management Enlightenment}

This research is of great significance for the practice of marketing management. In particular, there are two aspects as follows:

The first, we should attach great importance to the role of consumer responsibility and environmental responsibility. First of all, China's agricultural products enterprises should pay special attention to the responsibility of consumers, ensuring product quality in the process of production and processing to provide high quality products. And they should not exaggerate in the process of product advertising and sales to fulfill consumer responsibilities. Besides, enterprises should also deal with the wastes in the process of production and processing, minimize environmental pollution and improving the environment-protective of products to fulfill their environmental responsibilities.

The second, in the process of using social responsibility strategy, we should focus on the intermediary role of perceived risk. When facing the stimulus of the corporate social responsibility, the consumer will process the information to form the perceived risk and then form the brand trust. Therefore, agricultural enterprises in the application of corporate social responsibility strategy, they should firstly emphasizes the high quality of product in the process of information design and communication, so that consumers can form a positive judgment on the quality of products as well as reducing consumers' perceived risk to improve the consumer brand trust and enhance the effectiveness of the strategy.

\section{References}

[1] Brown T. J., Dacin P. A. The Company and The Product: Corporate Associations and Consumer Product responses [J]. Journal of Marketing, 1997, 61(1):68-84. 
[2] Sen S., Bhattacharya C. B., Korschun D. The Role of Corporate Social Responsibility in Strengthening Multiple Stakeholder Relationships: A Field Eexperiment [J]. Journal of the Academy of Marketing Science, 2006, 34(2):158-166.

[3] Pérez R. C. Effects of Perceived Identity Based on Corporate Social Responsibility: The Role of Consumer Identification with Company [J]. Corporate Reputation Review, 2009, 12(2):177-191.

[4] Liu Fengjun, Li Hui. The internalization mechanism of corporate association on brand attitude under the background of social responsibility: Based on the theory of reciprocity and identity [J]. Chinese soft science, 2014, (3): 99-118.

[5] Carroll A. B. A Three-Dimensional Conceptual Model of Social Performance [J]. Academy of Management Review, 1979, 4(4):497-505.

[6] Meng Fanfu. Research on corporate social responsibility from the perspective of consumers [D]. Shandong University doctoral thesis, 2013.

[7] Dowling G. R., Staelin R. A Model of Perceived Risk and Intended Risk-handling Activity [J]. Journal of Consumer Research, 1994, 21(1):119-34.

[8] Kaplan L. B., Szybillo G. J., Jacoby J. Components of Perceived Risk in Product Purchase: A Cross-Validation[J]. Journal of Applied Psychology, 1974, 5 9(3):287-291.

[9] Peter J. P., Tarpey L. X. Behavioral Decision Making: A Comparison of Three Models [J]. Advances in Consumer Research, 1975, 2(1):119-127.

[10] Delgado-Ballester E. Applicability of A Brand Trust Scale Across Product Categories [J]. Journal of Market Research, 2003, (45):38-39.

[11] Gurviez P., Korchia M. Proposal for A Multidimensional Brand Trust Scale[R]. 32th EMAC Conference, 2003.

[12] Yuan Denghua, Luo Siming, Li You. Brand trust structure and its measurement research [J]. Psychology Exploration, 2007, 27 (3): 81-86.

[13] Lau G. T., Lee S. H. Consumers' Trust in A Brand and The Link to Brand Loyalty [J]. Journal of Market-Focused Management, 1999, 4(4):341-370.

[14] Li Man, Ma Qinhai, Zhao Xiaoyu. The mechanism of network service scenarios on customer behavior intention: from the perspective of initial trust [J]. Journal of marketing science, 2014, 10 (2): 44-58.

[15] Chen Y. S., Chang C. H. Enhance Green Purchase Intentions: The Roles of Green Perceived Value, Green Perceived Risk, and Green Trust[J]. Management Decision, 2012, 50(3): 502-520.

[16] Eid M. I. Determinants of E-commerce Customer Satisfaction, Trust, and Loyalty in Saudi Arabia [J]. Journal of Electronic Commerce Research, 2011, 12(1):78-93.

[17] Jin Liyin. The movement of Corporate Social Responsibility Evaluation Index System--An Empirical Study on the consumer perspective [J]. Shanghai management science, 2006, (6): 114-120.

[18] Chen Rui, Zheng Yuhuang, Liu Wenjing. Analysis of intermediary effects: principles, procedures, Bootstrap methods and the uses [J]. Marketing Science Journal, 2014, (9): 120-135.

[19] Hair et al. Multivariate data analysis analysis (6thed). Upper Saddle River, NJ: Prentice Hall [M]. 2006:118-121.

[20] Yuan Denghua, Luo Siming, Tang Chunyan et al. Study on driving mechanism of brand trust antecedents and consequences [J]. Psychological science, 2008, 31 (9): 1334-1338. 